論説

\section{EBMと鍼炎臨床}

矢野 忠

明治鍼尒大学臨床鍼尒医学教室

\title{
Acupuncture and Moxibustion in the Context of Evidence-Based Medicine
}

\author{
Tadashi YANO \\ Department of Clinical Acupuncture and Moxibustion, \\ Meiji University of Oriental Medicine
}

キーワード：EBM、鍼尒、POD

Keywords : Evidence-Based Medicine, Acupuncture and Moxibustion, Patient Oriental Medicine

\section{PODの重要性}

医学研究には、疾患立脚型研究 (disease oriented research; DOR) と患者立脚型研究（patient oriented research；POR）とがある1”。DORとは、 疾病の発症機序の解明や根本的治療の開発を主目 的としており、動物あるいはヒトの組織、細胞を 対象とした研究である。一方、PORとは、診断方 法および治療法の有効性の評価をあくまでも個体 としての生きている患者あるいは健常人を対象に 行う研究である。我が国の医学界では、依然とし てDORというパラダイムが席巻している。その風 潮は鍼多医学においても同様で、ハリ麻酔の機序 の解明に端を発した鍼尒研究の流れは、年々その 傾向を強くしている。

今日、急性疾患から慢性疾患へと疾病構造が变 化し、様々な問題（医療的、社会的）が噴出して きたが、それらの問題を解決するには、従来の特 異的病因論による医学 (DOR重視の医学) では限 界があるとして、PORの必要性が強調されるよう になつてきた。特に生活習慣病の研究に象徵され るように臨床疫学 (clinical epidemiology) 的な視 点の重要性が強調されるようになってきた。ここ
でいう臨床疾学とは、「(生物統計学、決断科学、 コンピュー夕科学、心理社会学などを含む、いわ ゆる）疫学的手法を応用して、医学の診療行為や 検査法、治療法などの有效性と効率性を評洒する 学問」である2l。言い換えればEvidence-Based Medicine（EBM）のパラタダイムが重要視される ようになってきた、ということである。そのよう な医学界の潮流は当然ながら鍼炎界にも大きく影 響し、その反応はNIHパネルによる鍼に関する合 意形成声名 (NIH Panel Issues Consensus Statement on Acupuncture, 1997年11月5日） 3.4) となって現れ た、とみていいであろう。

\section{EBMの流れ}

そもそもEvidence-Based Medicine (EBM) とは いったいどのようなものか、「現時点で得られた 最良の科学的根拠を検査あるいは治療を選ぶ場合 に誠実かつ注意深く用いること」5) あるいは「入 手可能な範囲内で最も信頼できる根拠を把握した 上で、個々の患者に特有の臨床状況と患者の価値 観を考慮した医療を行うための一連の行動指針」 2)であるとされている。すなわちEBMを実践する 
ためには、最も信頼できる科学的根拠があること、 そしてそれらが入手可能な状沉にあること、が必 要である。

であるとすれば銊尒臨床においてEBMを実践す ることは、現時点で極めて困難であると言わざる えない。その理由の一つが、NIHの「鍼について の合意形成声明書」に示された“評価に耐えうる 十分なデー夕に基づきプラセボや偽銊と比較した とき、鍼は効くと言えるのか”に応えるだけの質 の高いエビデンス（科学的根拠）が未だ不十分で あるからである。これらのエビデンスを得るには、 ランダム化比較試験 (randomized controlled trial;RCT）による臨床研究を強力に推進しなけれ ばならないと指摘されている。

RCTとは、ある集団をランダムに2群以上に割 り付け、一定期間追跡の後に、介入に影響があっ たかどうかを調べる臨床研究の方法のことである 6!。この方法は最もバイアスの影響が少ないこと から介入の効果を調べるときには最適な方法であ るとされ、EBMを進展させるには欠かすことの出 来ない研究方法論とされている。しかしながら、 ランダム化に伴う倫理的な問題や臨床研究の場が 得にくいなどのためRCTによる臨床研究の実施は 非常に困難であり、思うように進まない現状があ る。

\section{EBMの難しさ}

NIHの鍼に関する合意形成声明書に示されてい るように、我が国においても近い将来、科学的根 拠に基づいた銊尒医療（Evidence-Based Acupuncture and Moxibustion) が求められるよう になることであろう。しかし、それを構築し、実 践していくためには“ある環境”が必要であると 考える。

諸外国では銊炎医療は代替 (alternative medicine)、補完（相補）医療 (complementary medicine）あるいは代替・補完（相補）医療 (complementary and alternative medicine: CAM) と して位置づけられ、その臨床的効果については医 療機関や研究機関で㛜密な評価が行われようとし ていいる。特にアメリカでは、多くの医科大学に おいてCAMに関する教材を取り入れ、その教育の
普及を図る7ともにNIHの中に代替医療の部門 (NIH Office of Alternative Medicine. 設立し、科 学的な研究の推進と医療としての位置づけの検討 (例えばNIHの合意形成声明書で示された“鍼を現 在の保健医療体系に適切に組み入れるためには、 どんな問題に取り組む必要があるのか”等）がな されようとしている。

一方、我が国では鍼尒医療は伝統医学として悠 久の歴史を持ちながらも、未だ医業類似行為とし て医療の枠外に位置づけられたままである。その ため医療機関内での銊尒治療は正規の医療行為と して認められず、銊炎治療を行うことは原則禁止 である。少なくともこのような状沉下では臨椺研 究（ケースシリーズ、症例対照研究、RCTなど) を進めることは非常に困難である。

もしこのような状沉が緩和され、医師をはじめ とする医療関係者の銊尒に対する認識が改まり、 理解がすすめば多くの成果を上げることが出来る ものと期待される。例えばCardini F ( $^{8}$ は260例 の骨盤位の妊婦を対象に胎位矯正（逆子の治療） に対する至㓌の尒療法の効果についてRCTにより その有効性を実証したように、我が国に扔いても RCT上る臨床研究が展開されることであろう。前 途した「ある環境」とは、このことを指す。

しかし、現実の医療体制下では「ある環境」は 容易に与えら机るものではない。細々ではあるが 現体制下において質の高いエビデンスを生み出す 努力を続けなければならない。そしてそれらの積 み重ねによる成果を通して鍼尒医療に対する既成 概念を変えていくことが、医療機関内での臨床研 究の場の提供に慗がる道と考える。とはいうもの の開業が主体の鍼尒医療の構造においては、質の 高いエンビデンスを得るためのRCTによる臨床研 究は極めて困難であり、また一定の標本数を確保 することは至難なことである。多施設による共同 研究の方法論が確立されているとはいうものの、 そこには様々な制限が存在することも事実であり、 求められているような信頼の高いエビデンスを作 っていくことは大変難しいと言わざるを得ない。 また、銊尒師が日常臨床の中で比較的可能とされ ているN-of-trials ${ }^{9 !} や 1$ 事例反転法 ${ }^{10)}$ 等の臨床研 究も確立さ机ているが、それらを実施するにも多 
くの条件がついてまわる。

\section{抵抗感の背景}

EBMの基本理念に基ずく銊多医療の展開につい ては、理性的には誰も反対しないだろう。しかし、 感情的にはその導入において様々な抵抗（EBMに 対する誤解？）があるように感じられる。それは ある種の雲囲気のようなものであるが、それを問 題として取り上げられたことはなく、むしろ避け てきたようにさえ思える。今後、科学的根拠に基 ついた鍼多医療を検討し、導入を図っていくとす れば、暖昧模湖とはしているものの“ある種の抵 抗感”について真摰に議論し、一定のコンセンサ スを形成することが必要ではなかろうか。ここで は“ある種の抵抗感”が生み出される背景につい て考え、一つの論点 (単なる誤解かも知れない) を提供できればと思う。

\section{1）鍼炎医療の役割}

鍼尒医療は、明治以来長年にわたって医業類 似行為として医療の枠外に存在し、その役割を 担ってきた。その役割とはいったいどのような ものであったか。そ机は疾病の治療なのか、症 状の管理なのか、未病治的な役割なのか、QOL の向上なのか、健康維持・増進なのか、様々な 医療的役割を挙げることができるが、実際のと ころ判然としない。いうな机ば多様な役割を担 ってきたというところであろうか。

しかしながら、これらの役割は銊尒師側から みた役割であり、鍼炎医療の受療者（患者）あ るいは利用者は、実際のところ鍼尒医療に何を 求めてきたのであろうか、また何を期待してい るのであろうか、明確ではない。こ机ほどまで に普及した現代医療体制の中で医業類似行為と して存続し続けてきた事実からいって、鍼炎医 療には現代医療とは異なる役割が求められてき たのではなかろうか、と直感する。残念ながら この点についての研究は皆無であり、臨床疫学 的な研究の必要性を痛感する。

しかし、日々臨床に立つ一人一人の銊尒師は 鍼尒医療の真の役割を肌で感じ取っているはず である。それは疾患あるいは身体症状に対する 治療だけではない何かを。いうなれば鍼多師は
個々の患者との交流の中で患者の苦しみ、悲し みといった機微までも含めた全人的な医療、個 の医療（一人一人の患者に対する適切な医療） の価値を知っているはずである。そこに鍼多医 療の本質的な価值と役割を見出しているとすれ ば、はたして科学的根拠に基づく鍼尒医療は、 それらをどのように組み入れてくれるのか、い わば人間性の評価（QOL等）、尊重を含めて今 後発展していくことが可能であるのか、そうい ったことが見えにくいことに“ある種の抵抗感” が生まれる背景があるのではないだろうか。

\section{2）治療効果の評価}

ある治療方法の効果を評価するにはエンドポ イントが設定される。エンドボイントには真の エンドポイント（ture endpoint）と代理のエン ドポイント (surrogate endpoint) とがある11!。 真のエンドポイントと代理のエンドポイントと の関係は、例えば高血压症に対する真の効果は 死亡率の減少であるが、そのようなことを評価 するには長時間の観察が必要であり、短期間内 で評価することはできない。従って多くの場合 は、死亡率の低下は血圧を下げることによって 得られるはずであるから血圧をエンドポイント として用いる。この場合のエンドボイントが代 理のエンドポイントである。真のエンドポイン トと代理のエンドホイントとの関係が明確でな い場合も多くあることから、どのようなエンド ボイントを設定するかによって効果の評価は異 なってくる。鍼多治療の効果を評価する場合も、 このことは十分認識しておかなければならない。 一方、鍼尒医療の場合、独自の病因論や治療論 より成り立っていることから、評価に扔いて現 代医学的な枠組みの他にもう一つの枠組み、東 洋医学による枠組みが成立する。従って評洒に あたっては両者の枠組みによるエンドポイント の設定が考えられるが、両者の関係についての 研究は残念ながら皆無である。この問題を今後、 どのように解決していくか、といった懸念もあ る。

更にエンドポイントには客勘的なものと主観 的なものとがある。痛みや気分あるいはQOL等 は主観的尺度に寄らざるを得ないが、研究にお 
いては主観的なエンドポイントは客観性が欠け るとして客観的尺度が重視される。鍼炎治療に よって生ずる快適性、満足感等のアメニティー は、全人的医療の観点からみると非常に重要な 意味をもつものの、その評価は低い。はたして 科学的根拠に基づく鍼尒医療では、これらの効 果が正当に評価されるのか、といった懸念があ る。

\section{3）対象患者の特殊性}

鍼炎治療を受療する患者の多くは、医療機関 を経てきたり、あるいは医療機関にかかりなが ら銊炎治療を受療する。そういった意味におい て医療機関での受療者とは異なった集団である と捉えることができる。正統医学としての現代 医学が存在するにもかかわらず、患者自ら鍼炎 医療を選択したという特殊性がある。この特殊 性の意味は前述した現代医療に求めるものとは 異なった何かを銊尒医療に求めていることに繋 がるが、そのような特殊性を持った集団を臨床 研究の中でどのように取り扱うのか、といった 懸念がある。

\section{おわりに}

筆者は決してEBMパラダイムを否定しているも のではない。何故ならEBMの目的は、患者の利益 を最大化することにあるからである。だとすれば 当然ながら科学的根拠に基づいた銊多医療は必至 である。しかし、EBMを語る場合、多くは諸外国 の医療体制の視点からであり、日本における医療 体制、とりわけ鍼炎医療の実情をどの程度考慮し て語られているのか、その点にある種の不安を覚 える。諸外国では鍼尒医療はMedicineとして正統 に認知され、現代医学を補完するもう一つの医学 として位置づけられている。しかし、日本では未 だ正統医療の枠外におかれ、独自の役割を担って いるが、科学的な根拠に基づいた銊尒医療ではそ の役割が正しく組み込まれるのか、そのことが問 わ机ているように思える。

鍼尒医学は、日本の文化的な風土に溶け込んで 発展してきた伝統医療である。その場は常に庶民 の中にあった。このような伝統医学としての鍼尒 医学を止揚し発展させるには、歴史的な伝統を活
かしながら、現在の問題に接近していく方策を模 索することが、科学的な根拠に基づく鍼多医療を 構築する道ではないかと考える。

\section{参考文献}

1) 福原俊一、ジョセフ・グリーン：患者立脚型 研究のすすめ、EBM、1：106-110、1999.

2 ) 福井次矢 : EBMの歴史的背景と意義、EBM 実践ガイド (福井次矢編著)、pp1-6、医学書 院、東京、1999.

3 ) 津谷喜一郎、渡邊 裕ら訳：NIHパネルによ る鍼に関する合意声明について、全日本鍼炎 学会雑誌、47：307-309、1997.

4 ) 全日本鍼多学会雑誌編集部: 米国国立衛生研 究所 (NIH) 合意形成声明 最終版、全日本 銊尒学会雑誌、48：186-193、1998.

5 ) 桑間雄一郎、大庭祐二：EBM（科学的根拠に 基づいた医療）、治療、81：1341-1349、1999.

6 ）松村真司：EBMが認めるのはランダム化比較 試験であるという䛊解、EBM、1：28-33、 1999.

7 ) Miriam S. Wetzel, et al : Courses involving Complementary and Alternative Medicine at US Medical Schools, JAMA, $280 ： 784-787$, 1998.赤 井真弓、赤井靖宏訳、尾島昭次監修: 米国医 科大学に拈いて補完医療掞よび代替医療を取 り入机ている科目、JAMA (日本語版)、2、 87-92、1999.

8 ) Cardini F. et al. : Moxibustion for correction of breech presentation: a randomized controlled trial., JAMA; 280(18)：1580-1584，1998.中村行 雄訳：殿位矯正に対する尒の効果、ランダム 化比較試験、JAMA (日本語版)、7、100106、1999.

9 ) 岡山雅信：N-of-1 trials、診断と治療：86、 1913-1918、1999.

10）桑田 繁：新しい実験計画としての単一被験 者の紹介、全日本鍼炎学会雑誌：43、28-43、 1993.

11）津谷喜一郎：集団に効くことと個人に効くこ と一「効き目」のコミュニケーション、日本 東洋医学雑誌、48：569-598、1997. 